\title{
Effect of Feeding a Low Crude Protein Diet on Growth Performance of Finishing Pigs at a High Ambient Temperature
}

\author{
Makoto YAMAZAKI ${ }^{1,2 *}$, Hiroaki INOUE ${ }^{1}$, Mitsuhito MATSUMOTO ${ }^{1}$ and \\ Yuji KAJI \\ ${ }^{1}$ Livestock and Grassland Research Division, Kyushu Okinawa Agricultural Research Center, \\ National Research and Development Agency, National Agriculture and Food Research \\ Organization (Koshi, Kumamoto 861-1192, Japan)
}

\begin{abstract}
The effects of reducing dietary crude protein $(\mathrm{CP})$ in a high temperature environment $\left(32^{\circ} \mathrm{C}\right)$ on growth performance and back fat deposition were investigated in finishing pigs. Twelve barrows $(80.9 \pm 7.6$ $\mathrm{kg}$ ) were allotted randomly to two dietary regimens $(13.9 \% \mathrm{CP}$ vs $11.8 \% \mathrm{CP})$ and were fed the diets for 4 weeks. The low-CP diet $(11.8 \% \mathrm{CP})$ was supplemented with amino acids to meet the nutritional requirements. At the end of the experiment, back fat thickness, plasma urea nitrogen, and amino acid concentration were measured for all the barrows. The dietary CP level did not have any effect on growth performance, back fat thickness, or the plasma urea nitrogen concentration of the finishing pigs. Plasma free lysine, threonine, and methionine concentrations were higher in pigs that were fed the low$\mathrm{CP}$ diet. These results indicate that reducing dietary $\mathrm{CP}$ by two percentage points does not alleviate the negative effect of heat stress and may not affect fat deposition.
\end{abstract}

Discipline: Animal industry

Additional key words: amino acids, fat deposition

\section{Introduction}

According to the prediction of the Intergovernmental Panel on Climate Change (2013), average global temperature may increase by up to $4.8^{\circ} \mathrm{C}$ by 2100 . This indicates that the negative effects of heat stress on livestock production will become more apparent in the future as average global temperature increases. Finishing pigs are susceptible to high ambient temperatures due to their poor ability to dissipate heat (Renaudeau et al. 2011). To alleviate heat stress in finishing pigs, several dietary strategies have been evaluated (Renaudeau et al. 2012). Growth performance improved in heat-stressed finishing pigs fed fat-supplemented diets (Stahly \& Cromwell 1979, Katsumata et al. 1996). Reduction in the dietary CP level in feeds may be another method to improve growth performance in heat-stressed finishing pigs, because digestion of dietary protein and protein (amino acids) metabolism increases animal heat production (Forbes \& Swift 1944, Stahly et al. 1979). Stahly et al. (1979) reported improvement in growth performance through feeding low-CP diet in a high temperature environment. Spencer et al. (2005) also observed 7.4\% higher average daily gain in finishing pigs fed an $11.3 \% \mathrm{CP}$ diet compared to pigs fed a $13.6 \% \mathrm{CP}$ diet, under temperature variations between $27^{\circ} \mathrm{C}$ and $35^{\circ} \mathrm{C}$. However, an increase in carcass fat content occurred when pigs consumed feeds with reduced dietary CP but with constant energy content (Tous et al. 2014). Dauncey \& Ingram (1983) and Christon (1988) demonstrated that body fat accumulation was greater in pigs kept at high ambient temperatures than those kept at low ambient temperatures. Thus, feeding low-CP diets to finishing pigs in a high temperature environment may accelerate fat storage and may affect meat quality.

The objective of this study was to determine whether

\footnotetext{
Present address:

${ }^{2}$ Institute of Livestock and Grassland Science, NARO (Tsukuba, Ibaraki, 305-0901, Japan).

* Corresponding author: e-mail yamazaki@affrc.go.jp

Received 20 November 2017; accepted 30 March 2018.
} 
feeding a low-CP diet fortified with amino acids could improve growth performance, as well as affect backfat thickness.

\section{Materials and methods}

All the experimental procedures were carried out in accordance with animal experiment regulations and the approval of the Animal Experiment Committee of Kyushu Okinawa Agricultural Research Center.

Twelve barrows (Duroc $\times$ (Large White $\times$ Landrace cross breed)) with an initial average body weight of 80.9 \pm 7.6 (S.D.) $\mathrm{kg}$ were used in this experiment, although one barrow from the control treatment group was withdrawn from the experiment in the first week due to a leg abnormality. For the first seven days, the pigs were assigned to individual pens $(1.30 \times 2.46 \mathrm{~m})$ with concrete flooring in a temperature-controlled room $\left(22^{\circ} \mathrm{C}\right)$ and were fed a conventional corn-soybean meal based diet. Then, the pens were randomly allocated to two dietary regimens (control and low-CP diet, Table 1), with six pens per dietary regimen. At $1000 \mathrm{~h}$ in the first day of the experiment, room temperature was increased to $32^{\circ} \mathrm{C}$,

Table 1. Composition of experimental diets

\begin{tabular}{lrr}
\hline \hline & Control & Low-CP \\
\hline Corn & 80.85 & 86.47 \\
Soybean meal & 15.00 & 9.00 \\
Fish meal & 1.00 & 1.00 \\
Alfalfa meal & 1.00 & 1.00 \\
$\mathrm{Ca}_{3}\left(\mathrm{PO}_{4}\right)_{2}$ & 1.60 & 1.60 \\
$\mathrm{NaCl}_{\text {L-Lysine-Cl }}$ & 0.30 & 0.30 \\
L-Threonine & - & 0.20 \\
DL-Methionine & - & 0.09 \\
L-Tryptophan & - & 0.06 \\
Vitamin mineral mixture & - & 0.03 \\
& 0.25 & 0.25 \\
Nutritional content ${ }^{2)}$ & & \\
$\quad$ Digestible Energy (kcal/g) & & \\
Crude Protein (\%) & 3.40 & 3.43 \\
$\quad$ Lysine (\%) & 13.90 & 11.80 \\
$\quad$ Methionine + Cystine (\%) & 0.66 & 0.67 \\
Threonine (\%) & 0.48 & 0.46 \\
Tryptophan (\%) & 0.53 & 0.53 \\
\hline
\end{tabular}

1) Vitamin mineral mixture provided the following (per $\mathrm{kg}$ of diet): vitamin A, 2,000 U; vitamin $\mathrm{D}_{3}, 300 \mathrm{U}$; $\mathrm{DL}^{-\alpha-}$ tocopheryl acetate, $10 \mathrm{mg}$; menadione sodium bisulphate, $534 \mu \mathrm{g}$; riboflavin, $2 \mathrm{mg}$; ${ }_{\mathrm{D}}$-calcium pantothenate, $2.2 \mathrm{mg}$; nicotinic acid, $2.6 \mathrm{mg}$; choline chloride, $100 \mathrm{mg}$; pyridoxine hydrochloride, $1.2 \mathrm{mg}$; folic acid, $250 \mu \mathrm{g}$; thiamine mononitrate, $600 \mu \mathrm{g}$; cyanocobalamin, $3.0 \mu \mathrm{g}$; iron, $30 \mathrm{mg}$; manganese, $25 \mathrm{mg}$; zinc, $35 \mathrm{mg}$; copper, $6.5 \mathrm{mg}$; iodine, 0.5 $\mathrm{mg}$

2) Analyzed value; only digestible energy content is a calculated value. with relative humidity around $60 \%$. Pigs had free access to diets and water, and the diets were added to each feeder at $0900 \mathrm{~h}$ each day. The remaining uneaten diet in each feeder was collected and weighed once a week. Both diets were mash formed and fortified with the nutritional requirements of the Japanese Feeding Standard for Swine (2013), with the exception of the CP content for the lowCP diet.

The body weights of the pigs were measured once a week. Back fat depth was estimated at the P2 position (65 $\mathrm{mm}$ below the left side from the midline over the last rib), using an ultrasonic scanner (HS-101V, Fujihira Industry Co., Ltd., Tokyo, Japan) at weeks 0 (the day before heat exposure), 2, and 4 (the day before the end of the experiment). On the final day prior to the end of the experiment, blood samples were collected at $0930 \mathrm{~h}$ from all pigs via jugular vein puncture. Plasma was obtained by centrifuging at $1,800 \times g\left(4^{\circ} \mathrm{C}\right.$ for $15 \mathrm{~min}$ ), and it was stored at $-80^{\circ} \mathrm{C}$ until analysis. Plasma urea nitrogen concentration was determined at LSI Medience Corporation (Tokyo) according to the method of urease-leucine dehydrogenase. Plasma was deproteinized with $6 \% 5$-sulfosalicylic acid solution, and free amino acid concentrations were determined with a high-speed amino acid analyzer (L-8800E, Hitachi High Technologies Co., Tokyo, Japan). Dietary CP content was determined according to the method described by AOAC (2003). Amino acid content of the experimental diet was determined at Japan Food Research Laboratories according to the method described by AOAC (2003).

A computer-generated SAS application package (SAS Institute 1988) was used for statistical calculations. Student's t-test was used to analyze the data. The level of significance used was $P<0.05$.

\section{Results and discussion}

The results of this study suggest that growth performance of finishing pigs was not improved with a reduction of two percentage points of dietary CP (Table 2). In contrast, Spencer et al. (2005) observed approximately $7 \%$ improvement in average daily gain with feeding

Table 2. Effect of dietary CP level on growth performance of finishing pigs at high ambient temperature

\begin{tabular}{lrr}
\hline \hline & \multicolumn{1}{c}{ Control $^{1)}$} & \multicolumn{1}{c}{ Low-CP } \\
\hline Average daily gain (g/day) & $824 \pm 114^{3)}$ & $813 \pm 175$ \\
Average daily feed intake (g/day) & $2966 \pm 446$ & $2853 \pm 598$ \\
Feed efficiency (gain/feed) & $28.1 \pm 4.6$ & $28.6 \pm 2.8$ \\
\hline
\end{tabular}

1) $\mathrm{n}=5$

2) $\mathrm{n}=6$

3) Average \pm S.D. 
low-CP diets (also reduced by two percentage points) in finishing pigs; however, their methods included cycling high ambient temperatures $\left(27^{\circ} \mathrm{C}\right.$ from 1900 to $1000 \mathrm{~h}$, $35^{\circ} \mathrm{C}$ from 1000 to $1900 \mathrm{~h}$ ), while the pigs in the present study were kept at a constant high ambient temperature of $32^{\circ} \mathrm{C}$. The variation in the results of the two experiments could also be attributed to the differences in other experimental conditions such as strain of pigs, relative humidity, or composition of experimental diets. Le

Table 3. Effect of dietary CP level on plasma urea nitrogen and plasma free amino acid concentration of finishing pigs at high ambient temperature

\begin{tabular}{lcc}
\hline \hline & Control $^{1)}$ & Low-CP \\
\hline Plasma urea nitrogen $(\mathrm{mg} / \mathrm{dl})$ & $14.6 \pm 2.7^{3)}$ & $11.2 \pm 3.5$ \\
Plasma essential amino acids $(\mathrm{nmol} / \mathrm{ml})$ & \\
Arginine & $273 \pm 29$ & $261 \pm 34$ \\
Histidine & $114 \pm 9$ & $108 \pm 16$ \\
Isoleucine & $148 \pm 19^{\mathrm{a}}$ & $127 \pm 10 \mathrm{~b}$ \\
Leucine & $302 \pm 26$ & $311 \pm 17$ \\
Lysine & $259 \pm 46^{\mathrm{b}}$ & $364 \pm 62^{\mathrm{a}}$ \\
Methionine & $68.8 \pm 4.5^{\mathrm{b}}$ & $95.5 \pm 20.4^{\mathrm{a}}$ \\
Cystine & $62.7 \pm 3.0$ & $62.7 \pm 6.6$ \\
Phenylalanine & $132 \pm 9$ & $122 \pm 7$ \\
Tyrosine & $162 \pm 10$ & $163 \pm 9$ \\
Threonine & $248 \pm 46^{\mathrm{b}}$ & $310 \pm 21^{\mathrm{a}}$ \\
Tryptophan & $82.2 \pm 2.2$ & $92.5 \pm 10.9$ \\
Valine & $348 \pm 45$ & $306 \pm 31$ \\
Plasma non-essential amino acids $\left(\mathrm{nmol} / \mathrm{ml}^{2}\right)$ & \\
Alanine & $562 \pm 64$ & $588 \pm 105$ \\
Aspartic acid & $4.45 \pm 1.20$ & $4.11 \pm 0.57$ \\
Glutamic acid & $53.4 \pm 13.6$ & $64.9 \pm 17.1$ \\
Glycine & $1172 \pm 122$ & $1402 \pm 312$ \\
Serine & $191 \pm 14$ & $229 \pm 37$ \\
Proline & $439 \pm 73$ & $419 \pm 28$ \\
\hline
\end{tabular}

1) $\mathrm{n}=5$

2) $\mathrm{n}=6$

3) Average \pm S.D.

a,b) Means in the same row with different superscripts differ significantly $(P<0.05)$

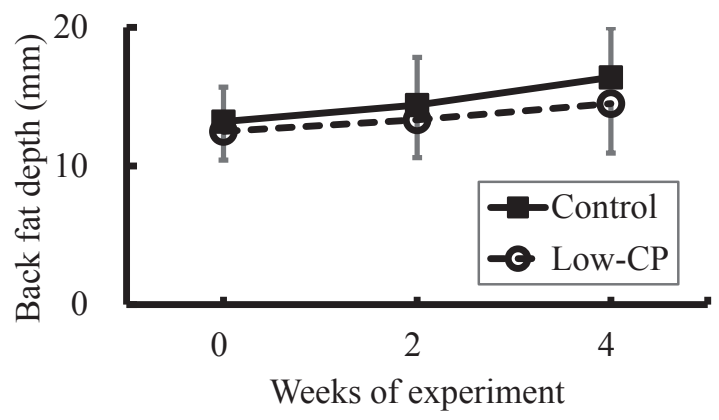

Fig. 1. Effect of dietary CP level on back fat depth (P2 position) of finishing pigs at high ambient temperature.

Data are expressed as mean \pm S.D.
Bellego et al. (2002) reported that growth performance of finishing pigs was not affected by the reduction in the dietary CP level (reduced by four percentage points). They compared feed intake of pigs fed the same diet at different environmental temperatures $\left(22^{\circ} \mathrm{C}\right.$ vs $\left.29^{\circ} \mathrm{C}\right)$, and observed that relative feed intake decreased with increased fattening in pigs fed the control CP diet; however, the relative feed intake did not decrease with growth in pigs fed the low-CP diet. Their results indicate that feeding a low-CP diet might alleviate the loss of appetite under high ambient temperatures; however, these effects may be too insignificant to affect growth performance.

Plasma urea concentration may be an index to monitor dietary protein sufficiency and dietary amino acid pattern in growing pigs (Coma et al. 1995), since increasing amino acid utilization decreases urea synthesis and, thus, decreases plasma urea concentrations. In the present study, there was no significant difference in plasma urea concentration between dietary treatments (Table 3), which confirms that the protein level of the low-protein diet was adequate and the amino acid pattern was suitable for finishing pigs. Although the expected advantages of the low-CP diet on finishing pigs were not observed, growth performance of finishing pigs was not hampered by the reduction of two percentage points of dietary $\mathrm{CP}$ level with essential amino acid supplementation (Kerr et al. 1995). Dietary supplementation with lysine, threonine, and methionine in the low-CP diet increased plasma levels of these free amino acids, and may be related to the higher supplementation of synthetic formed those amino acids in low-CP diet.

Figure 1 illustrates the change in back fat depth in pigs fed the low-protein and control diets, and suggests that the low-CP diet does not accelerate back fat accumulation. Similarly, Tachibana \& Ubagai (1997) found that there was no difference in fat thickness at the shoulder, back, and loin between pigs fed a low-CP diet $(11.5 \% \mathrm{CP})$ compared to pigs fed a $14 \% \mathrm{CP}$ diet. However, Tous et al. (2014) reported that finishing barrows fed an amino acidfortified low protein diet tended to have increased back fat thickness. They speculated that the change in carcass composition may be attributed to the replacement of the protein source by carbohydrates in the diet, and the energy for nitrogen excretion was distributed to fat synthesis. Further studies are necessary to clarify the different results of these experiments.

\section{Acknowledgements}

We are grateful to the staff of the Swine Section at the National Agricultural Research Center in the Kyushu Okinawa Region for their technical assistance 
in sample collection and feeding of the barrows. This study was supported by the Ministry of Agriculture, Forestry, and Fisheries, Japan, through a research project entitled "Development of technologies for mitigation and adaptation to climate change in agriculture, forestry, and fisheries."

\section{References}

AOAC. (2003) Official Method of Analysis of the Association of Official Analytical Chemists, $17^{\text {th }}$ ed. Association of Official Analytical Chemists, Washington, D. C. Arlington, VA.

Christon, R. (1988) The effect of tropical ambient temperature on growth and metabolism in pigs. J Anim Sci, 66, 31123123.

Coma, J. et al. (1995) Use of plasma urea nitrogen as a rapid response criterion to determine the lysine requirement of pigs. J Anim Sci, 73, 472-481.

Dauncey, M. J. \& Ingram, D. L. (1983) Evaluation of the effects of environmental temperature and nutrition on body composition. J Agr Sci, 101, 351-358.

Forbes, E. B. \& Swift, R. W. (1944) Associative dynamic effects of protein, carbohydrate and fat. J Nutr, 27, 453-468.

Intergovernmental Panel on Climate Change (IPCC) (2013) Climate Change.

Katsumata, M. et al. (1996) Growth and carcass fatness responses of finishing pigs to dietary fat supplementation at a high ambient temperature. Anim Sci, 62, 591-598.

Kerr, B. J. et al. (1995) Effect on performance and carcass characteristics of nursery to finisher pigs fed reduced crude protein, amino acid-supplemented diets. J Anim Sci, 73,
433-440.

Le Bellego, L. et al. (2002) Effect of high temperature and lowprotein diets on the performance of growing-finishing pigs. J Anim Sci, 80, 691-701.

National Agriculture and Food Research Organization. (2013) Japanese Feeding Standard for Swine.

Renaudeau, D. et al. (2011) A meta-analysis of the effect of high ambient temperature on growing-finishing pigs. J Anim Sci, 89, 2220-2230.

Renaudeau, D. et al. (2012) Adaptation to hot climate and strategies to alleviate heat stress in livestock production. Anim, 6, 707-728.

Spencer, J. D. et al. (2005) Diet modifications to improve finishing pig growth performance and pork quality attributes during periods of heat stress. J Anim Sci, 83, 243-254.

Stahly, T. S. \& Cromwell, G. L. (1979) Effect of environmental temperature and dietary fat supplementation on the performance and carcass characteristics of growing and finishing swine. J Anim Sci, 49, 1478-1488.

Stahly, T. S. et al. (1979) The effect of environmental temperature and dietary lysine source and level on the performance and carcass characteristics of growing swine. J Anim Sci, 49, 1242-1251.

Tachibana, F. \& Ubagai, H. (1997) Effect of reducing crude protein and energy content in diets with amino acid supplementation on nitrogen balance, performance and carcass characteristics in pigs. Anim Sci Technol, 68, 640649.

Tous, N. et al. (2014) Effect of reducing dietary protein and lysine on growth performance, carcass characteristics, intramuscular fat, and fatty acid profile of finishing barrows. J Anim Sci, 92, 129-140. 